\title{
ANALISIS KINERJA EKSPOR KERTAS INDONESIA KE AMERIKA LATIN
}

\author{
Mira Marina ${ }^{1}$, Sri Mulatsih ${ }^{2}$ \\ ${ }^{1}$ Mahasiswa Ilmu Ekonomi, FEM IPB \\ ${ }^{2}$ Staff Pengajar FEM IPB
}

\begin{abstract}
In order to increase the trade flow, Indonesia joined an alliance called as SouthSouth Cooperation and Forum for East Asia-Latin America Cooperation (FEALAC). One of commodity exported by Indonesia to Latin America is paper. This research purposes to analyze the competitiveness of Indonesian paper commodity in Latin America, and finding out factors affect paper export Indonesia to Latin America during 2009-2013, using RCA, EPD, gravity model and Porter's Diamond method. This research revealed that the average of $R C A$ is more than 1; three countries placed on the rising star, one country on lost opportunity position, two countries on falling star position, and two countries in retreat position. Variables affect export volume significantly are Per capita riel GDP of Indonesia and export destination country, export price, and economic distance, while exchange rate is not significantly affect the the exports.
\end{abstract}

Keywords: Competitiveness, EPD, Gravity, Porter's Diamond, RCA

\section{PENDAHULUAN}

\section{Latar Belakang}

Perdagangan Indonesia terutama dalam ekspor didominasi oleh sektor non-migas. Ekspor Indonesia berdasarkan sektor non-migas sekitar $82,79 \%$ dan ekspor migas sebesar $17,21 \%$ selama periode 2010-2014 dalam perkembangan perdagangan Indonesia (Kemenperin, 2016). Ada sepuluh komoditi unggulan Indonesia yang menghasilkan nilai ekspor terbesar beberapa diantaranya yaitu kelapa sawit, besi dan mesin, tekstil, elektronik, karet, makanan dan minuman serta pulp dan kertas. Industri pulp dan kertas menjadi salah satu kelompok hasil industri dengan nilai ekspor terbesar yaitu sekitar US\$ 5,33 miliar (Kemenperin 2016). Indonesia memiliki iklim tropis dan hutan tanaman industri (HTI) yang memiliki luas sekitar 9,83 juta hektar pada tahun 2012 (APKI 2013). Hutan tanaman industri ini dapat menghasilkan serat alam berupa sumber bahan baku kertas sehingga membuat Indonesia berpotensi dalam ekspor komoditi kertas. Sepuluh kelompok hasil industri dengan nilai ekspor terbesar Indonesia ditunjukkan pada Gambar 1.

Produksi kertas saat ini mencapai 10,4 juta ton per tahun dan pulp sebesar 6,4 juta ton per tahun (Kemenperin, 2015). Kinerja ekspor pulp dan kertas masing-masing sebesar 3,5 juta ton pulp dengan nilai sebesar US\$1,72 miliar atau sekitar 23,5 triliun rupiah dan 4,35 juta ton kertas dengan nilai sebesar US\$ 3,75 miliar atau sekitar 51,2 triliun rupiah (BPS 2015). Indonesia menjadi produsen pulp dan kertas terkemuka di dunia. Industri kertas Indonesia berada pada peringkat keenam di dunia dan peringkat ketiga di Asia. 


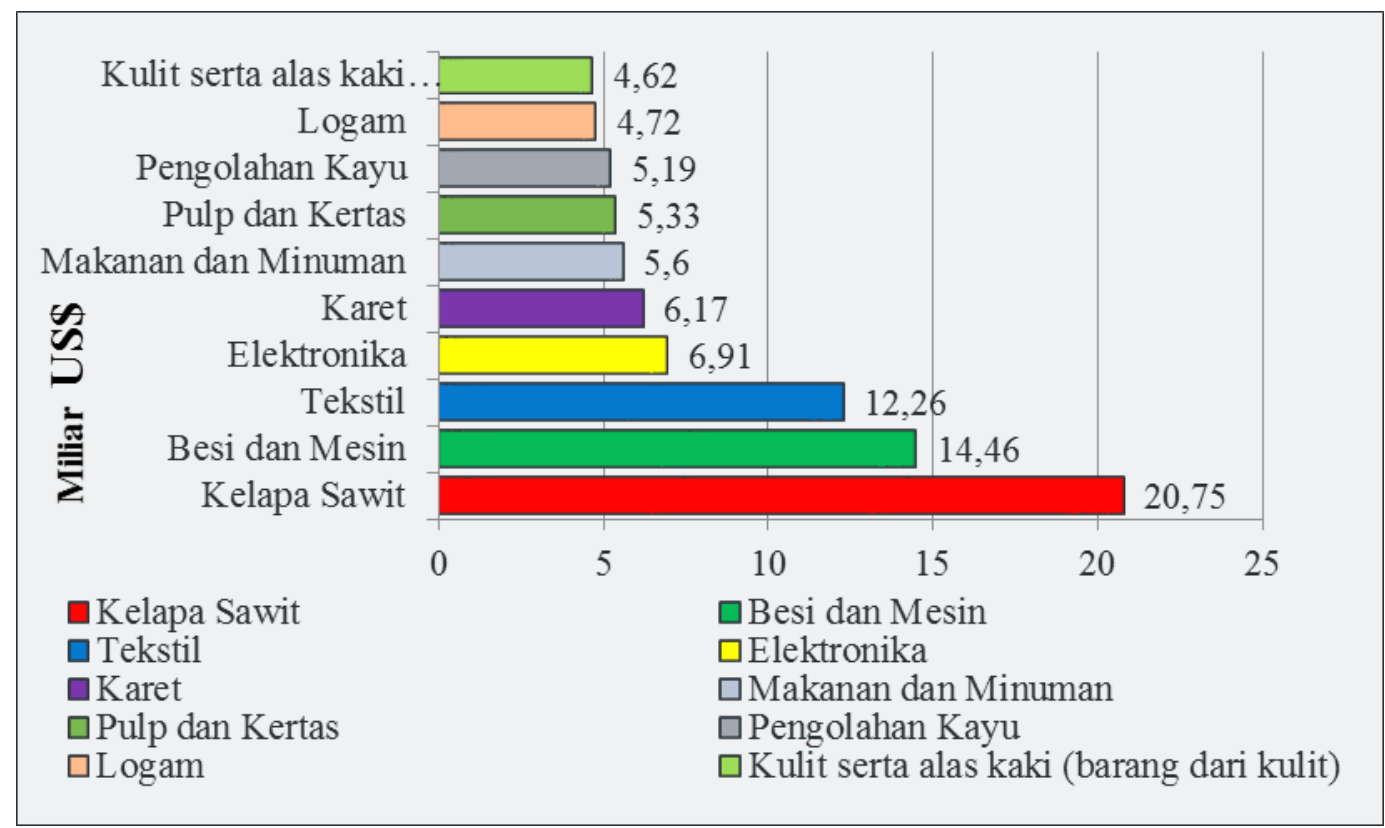

Sumber: Kementerian Perindustrian 2016

Gambar 1 Sepuluh kelompok hasil industri dengan nilai ekspor terbesar

Indonesia dalam rangka meningkatkan laju perdagangan dan memperkuat hubungan kerjasama dengan negara lain terutama negara bagian selatan, membuat suatu aliansi yang disebut dengan Kerjasama SelatanSelatan (KSS). Kerjasama ini sudah ada sejak tahun 1978 yang dimaksudkan untuk mepromosikan perdagangan Selatan-Selatan. Indonesia menjalin hubungan perdagangan ke kawasankawasan selatan ini salah satunya yaitu Amerika Latin. Indonesia dan Amerika Latin juga menjalin kerjasama pada Forum for East Asia - Latin America Cooperation (FEALAC) yang didirikan pada tahun 1999.

\section{Perumusan Masalah}

Krisis yang terjadi pada tahun 2008 dan 2010 di Amerika Serikat dan Eropa yang biasanya menjadi negara tujuan ekspor Indonesia memberikan dampak negatif pada perkembangan ekspor Indonesia. Pada periode Januari sampai September kinerja ekspor Indonesia tahun 2011 sekitar US\$ 152,2 miliar menurun sebesar $6 \%$ menjadi US\$ 143 miliar pada tahun 2012 di periode yang sama (BPS 2013). Hal ini membuat Indonesia harus mengalihkan ekspornya dengan cara memperluas pasar ke negara tujuan lainnya yang relatif tidak terkena krisis. Amerika Latin menjadi salah satu pasar ekspor yang potensial bagi Indonesia dan kertas merupakan salah satu komoditi yang menjadi unggulan ekspor Indonesia ke Amerika Latin. Perkembangan nilai ekspor kertas ke delapan negara di Amerika Latin dapat dilihat pada Gambar 2.

Gambar 2 menunjukkan kondisi ekspor kertas Indonesia ke Amerika Latin mengalami fluktuasi dari tahun 2009 sampai dengan tahun 2013. Namun kertas tetap menjadi komoditi unggulan Indonesia ke Amerika Latin. Berbagai upaya yang dilakukan Indonesia seperti melakukan kerjasama dalam KSS dan FEALAC diharapkan dapat meningkatkan daya saing ekspor komoditi unggulan Indonesia terutama kertas. 


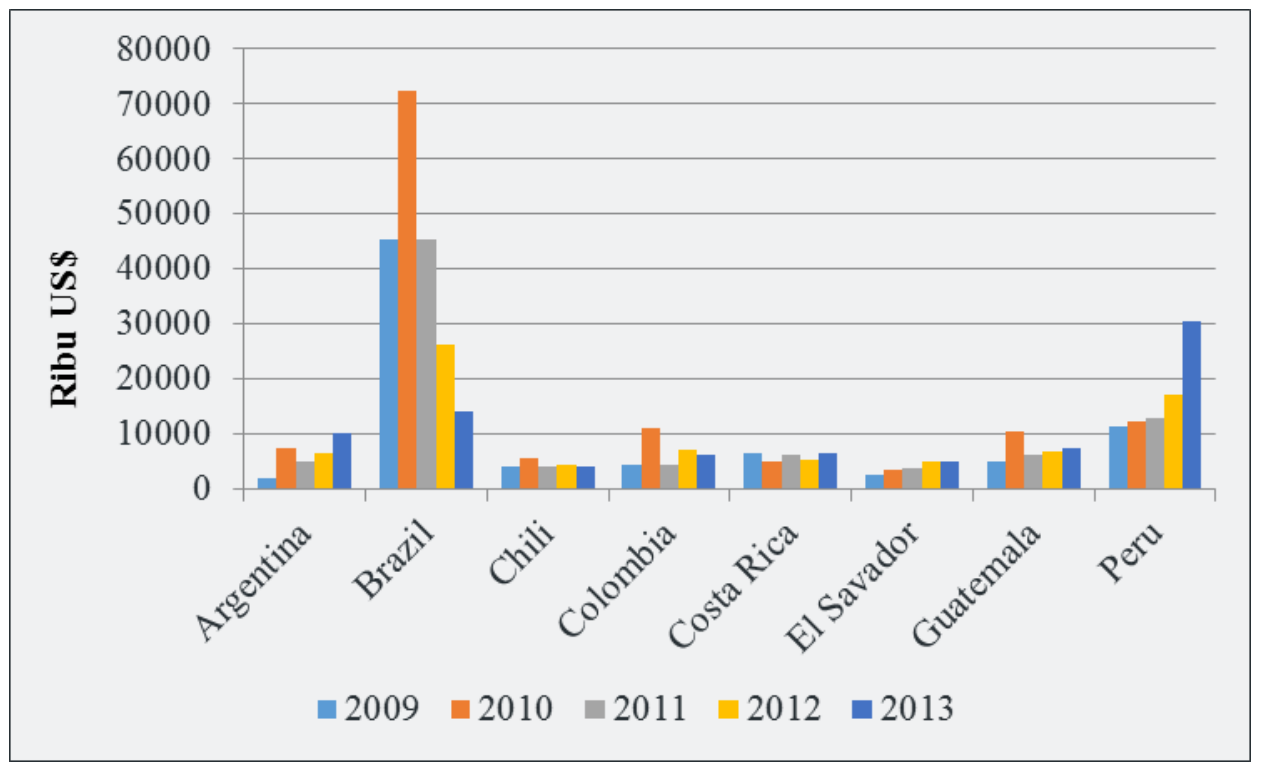

Sumber : ITC 2016

Gambar 2 Perkembangan Nilai Ekspor Kertas Indonesia ke Amerika Latin

Berdasarkan permasalahan di atas, penelitian ini bertujuan untuk menganalisis daya saing komparatif dan kompetitive ekspor kertas Indonesia ke Amerika Latin, dinamika ekspor kertas Indonesia ke Amerika Latin, mengetahui faktor-faktor yang memengaruhi ekspor kertas (HS4802 dan HS 2012) Indonesia ke Amerika Latin (Argentina, Brazil, Chili, Colombia, Costa Rica, El Savador, Guatemala, dan Peru).

\section{TINJAUAN PUSTAKA}

\section{Konsep Daya Saing}

Daya saing menjadi kriteria yang menentukan keberhasilan suatu negara di dalam perdagangan internasional. Daya saing merupakan kemampuan suatu komoditas untuk memasuki pasar luar negeri dan kemampuan untuk dapat bertahan dalam pasar Internasional. Menurut Porter (1990), daya saing diidentikkan dengan produktivitas dimana tingkat output yang dihasilkan untuk setiap unit input yang digunakan. Terdapat dua pendekatan yang sering digunakan untuk mengukur daya saing suatu komoditi dari dua indikator yaitu keunggulan komparatif dan keunggulan kompetitif.

\section{Teori Keunggulan Komparatif}

Hukum keunggulan komparatif menurut David Ricardo dalam Principles of Political Economy and Taxation (1817) ialah meskipun sebuah negara kurang efisien dibanding (atau memiliki kerugian absolut terhadap) negara lain dalam memproduksi suatu komoditi yang dihasilkan, namun kedua belah pihak masih tetap dapat melakukan perdagangan yang menguntungkan. Keuntungan dapat tercipta dengan melakukan spesialisasi produksi terhadap komoditi tertentu yang menjadi keunggulan komparatif negara tersebut. Maka, negara tetap dapat mengeskpor produk yang diproduksi relatif efisien dan juga dapat memenuhi kebutuhan negaranya terhadap suatu produk yang diproduksi relatif kurang efisien dengan cara mengimpor. 
Para ahli ekonomi lainnya yaitu Heckser dan Ohlin menyebutkan bahwa keuntungan komparatif juga ditentukan oleh kelimpahan faktor produksi. Suatu negara yang memiliki kekayaan faktor produksi dan mampu memanfaatkannya akan memproduksi barang dengan faktor produksi padat karya yang relatif lebih murah.

\section{Teori Keunggulan Kompetitif}

Teori keunggulan kompetitif menurut Porter (1990) ialah antara dua faktor produksi yang dimiliki suatu negara yaitu sumber daya alam yang melimpah dan sumber daya manusia yang murah, tidak ada korelasi langsung yang dimanfaatkan menjadi keunggulan dayasaing dalam perdagangan Internasional. Selanjutnya dinyatakan bahwa terdapat empat atribut utama yang dapat menentukan industri dalam suatu negara dapat bersaing di pasar internasional, yaitu:

1. Kondisi faktor produksi, seperti teknologi, infrastruktur yang memadai, dan tenaga kerja terampil.

2. Kondisi permintaan dan tuntutan mutu untuk barang dan jasa industri di dalam negeri.

3. Industri terkait dan industri pendukung yang kompetitif.

4. Strategi, struktur, dan persaingan perusahaan menentukan bagaimana perusahaan tersebut diciptakan, diatur, dan dikelola.

Selain keempat faktor tersebut, terdapat dua faktor lagi yang dapat memengaruhi interaksi keempat faktor yaitu faktor kebetulan atau kesempatan (chance events) seperti melonjaknya harga, perubahan nilai tukar, penemuan produk baru, konflik keamanan antar negara, dan lain-lain, serta faktor kebijakan pemerintah (government).

\section{Gross Domestic Product (GDP)}

Gross Domestic Product (GDP) merupakan nilai pasar semua barang dan jasa yang diproduksi oleh suatu negara pada periode tertentu. GDP Merupakan salah satu metode untuk menghitung pendapatan nasional. Hasil produksi barang dan jasa yang dihasilkan oleh perusahaan/orang asing yang beroperasi di wilayah negara yang bersangkutan juga masuk dalam perhitungan ini.

GDP juga mengukur dua hal pada saat bersamaan yaitu total pendapatan semua orang dalam perekonomian dan total pembelanjaan negara untuk membeli barang dan jasa hasil dari perekonomian. GDP suatu negara meningkat bisa melalui perdagangan bebas dalam aktivitas ekspor dan impor. Peningkatan GDP mengindikasikan peningkatan kemakmuran suatu Negara. Kemudian dari sisi konsumsi, output atau GDP akan digunakan dalam kegiatan konsumsi dan investasi oleh pemerintah dan para sektor swasta seperti eksportir (Dornbusch et al., 2008). Jika GDP meningkat, maka pendapatan juga meningkat sehingga konsumsi suatu negara juga meningkat.

GDP terbagi dua yaitu GDP riil dan GDP kapita. GDP riil merupakan nilai barang dan jasa yang diukur menggunakan harga konstan sedangkan GDP perkapita merupakan pendapatan rata-rata penduduk suatu negara pada periode tertentu.

\section{Nilai Tukar}

Nilai tukar antara dua negara adalah tingkat harga yang disepakati penduduk kedua negara untuk saling melakukan perdagangan (Mankiw 2007). Nilai tukar riil ekfektif (Real Effective Exchange Rate) adalah indeks dari nilai tukar nominal yang disesuaikan dengan pergerakan relatif dari harga domestik dari suatu Negara 
dan nilai perdagangan dengan negaranegara mitra dagangnya.

Jika REER Negara tujuan tinggi menunjukkan melemahnya nilai tukar negara tujuan atau terdepresiasi, maka harga barang-barang di negara tujuan relatif lebih murah dibandingkan dengan harga domestik. Kondisi ini mendorong penduduk luar negeri membeli produk domestik dalam jumlah yang sedikit sehingga menyebabkan ekspor domestik menurun. Sebaliknya, jika REER negara tujuan rendah, menandakan menguatnya mata uang negara tujuan relatif terhadap mitra dagang, maka harga barangbarang di negara tujuan relatif lebih mahal dibandingkan domestik. Kondisi ini akan meningkatkan ekspor domestik ke negara tujuan ekspor (Kemenperin, 2015).

\section{Harga Ekspor}

Harga merupakan faktor utama yang memengaruhi kegiatan ekspor. Harga dapat memengaruhi ekspor melalui dua sisi yaitu sisi penawaran dan Permintaan. Harga berhubungan positif pada jumlah ekspor yang ditawarkan namun memiliki hubungan negatif dengan jumlah ekspor yang diminta oleh negara pengimpor. Jika harga suatu komoditi meningkat maka permintaan terhadap suatu komoditi menurun sehingga ekspor akan menurun, namun jika harga suatu komoditi menurun maka akan meningkatkan permintaan ekspor terhadap komoditi tersebut. Rumus umum harga dijabarkan pada persamaan:

Harga ekspor $=\frac{\text { harga ekspor }}{\text { volume ekspor }}$

\section{Jarak Ekonomi}

Jarak adalah indikasi dari biaya transportasi yang dihadapi oleh suatu negara dalam melakukan ekspor.
Semakin jauh terpisah suatu negara dengan negara lainnya maka semakin besar pula biaya transportasi pada perdagangan antara keduanya. Penelitian ini menggunakan jarak ekonomi (JE), yaitu jarak geografis (JG) ibukota negara Indonesia dengan negara tujuan ekspor (j) dikalikan dengan perbandingan antara GDP total negara tujuan ekspor dengan jumlah GDP total seluruh negara tujuan ekspor yang diteliti (i Negara). Secara matematis dirumuskan sebagai berikut:

$\mathrm{JE}=\mathrm{JG} \times \frac{\text { GDP negara } k e-j}{\sum_{1}^{i} G D P \text { total i negara }}$

\section{Penelitian Terdahulu}

\begin{tabular}{lll}
\multicolumn{3}{c}{ Yunia (2015) menganalisis daya } \\
saing dan faktor-faktor & yang \\
memengaruhi & ekspor alas & kaki
\end{tabular}
Indonesia. Metode yang digunakan dalam penelitian ini adalah analisis RCA, EPD (Export Product Dynamic), dan gravity model. Hasil penelitian menunjukkan bahwa variabel yang signifikan pada taraf nyata $5 \%$ adalah GDP riil Indonesia berpengaruh negatif, GDP riil negara tujuan,jarak ekonomi, nilai tukar dan harga ekspor. Sedangkan variabel harga ekspor tidak berpengaruh pada nilai ekspor kertas Indonesia. Lalu pada hasil analisis RCA menunjukkan bahwa alas kaki Indonesia mempunyai posisi daya saing yang sangat tinggi dilihat dari nilai RCA yang mempunyai nilai rata-rata lebih besar dari satu. Sedangkan pada hasil estimasi EPD kertas Indonesia masih menempati posisi falling star pada enam negara di Amerika Latin yaitu Brazil, Chili, Paraguay, Peru, Uruguay, dan Venezuela. Dua negara lainnya menempati posisi retreat yaitu negara Argentina, dan Ekuador.

Firsya (2014) menganalisis daya saing dan faktor-faktor yang memengaruhi aliran ekspor komoditas kakao olahan Indonesia. Metode yang 
digunakan dalam penelitian ini adalah analisis RCA dan gravity model. Hasil penelitian menunjukkan bahwa mentega, lemak, dan minyak kakao Indonesia memiliki dayasaing yang relatif lebih baik dibandingkan dengan pasta dan bubuk kakao pada masingmasing negara tujuan ekspor. Faktorfaktor yang memengaruhi ekspor kakao olahan Indonesia pada HS 1803 adalah GDP riil Indonesia, GDP riil negara tujuan, populasi Indonesia dan negara tujuan, harga ekspor pasta kakao Indonesia, nilai tukar rill rupiah, jarak ekonomi, dan bea keluar biji kakao. Sedangkan pada komoditas HS 1804seluruh variabel tersebut berpengaruh signifikan. Sementara itu, pada komoditas HS 1805 terdapat dua variabel yang tidak signifikan memengaruhi aliran yaitu GDP negara tujuan dan jarak ekonomi.

Handayani (2008) menganalisis faktor-faktor yang memengaruhi aliran perdagangan dan strategi pengembangan ekspor kertas Indonesia. Penelitian ini menggunakan analisis gravity model untuk melihat faktor-faktor yang mempengaruhi ekspor kertas Indonesia dan analisis SWOT (Strength, Weakness, Opportunities, and Threats) untuk membuat strategi yang dapat mengembangkan ekspor kertas Indonesia. Hasil analisis gravity model menunjukkan bahwa faktorfaktor yang memengaruhi ekspor kertas Indonesia adalah GDP per kapita Negara tujuan ekspor, populasi negara tujuan ekspor, jarak ekonomi, dan harga kertas di negara tujuan. Sedangkan nilai tukar negara tujuan dan tuduhan dumping (dummy) tidak berpengaruh signifikan terhadap ekspor kertas Indonesia.

Karagoz dan Saray (2009) dalam judul penelitiannya Trade Potential of Turkey with Asia-Pacific Countries: Evidence from Panel Gravity Model, menganalisis faktor-faktor yang memengaruhi perdagangan Turki ke Asia Pasifik menggunakan gravity model. Hasil penelitiannya menunjukkan bahwa faktor-faktor yang memengaruhi adalah GDP negara tersebut dan jarak ekonomi. Sedangkan populasi tidak berpengaruh signifikan terhadap volume ekspor antara Turki dengan Asia Pasifik. Negara-negara yang berpotensi sebagai negara tujuan utamanya adalah P.N. Guinea, Peru, Myanmar, Meksiko, Laos, dan Brunei.

Utami (2008) menganalisis variabel-variabel determinan ekspor ASEAN: kasus Indonesia, Thailand, Singapura, Filipina Tahun 1990-2006. Penelitian ini dianalisis menggunakan gravity model dan ordinary least square. Hasil analisis menunjukkan bahwa variabel determinan ekspor Indonesia adalah proporsi output sektor manufaktur pada GDP, proporsi Gross Fixed Capital Formation pada GDP, Real Effective Exchange Rate, dan perubahan inflasi. Thailand dan Singapura memiliki determinan ekspor GDP per kapita dan proporsi sektor manufaktur pada GDP. Sedangkan Filipina, determinan ekspornya adalah indeks harga ekspor, proporsi Gross Fixed Capital Formation, Real Effective Exchange Rate, dan perubahan inflasi.

Yuniawati (2013) menganalisis daya saing dan faktor-faktor yang memengaruhi permintaan jahe dan temulawak Indonesia. Penelitian ini menggunakan analisis RCA, EPD, XModel Produk export potential, panel data serta Porter's Diamond. Hasil penelitian menunjukkan bahwa jahe memiliki keunggulan komparatif hanya di negara Belanda, sedangkan temulawak memiliki keunggulan komparatif di negara Amerika Serikat, Belanda dan Singapura. Namun hampir di semua negara sample jahe dan temulawak memiliki posisi 
pasar "Rising star" kecuali di negara Jepang yaitu Lost Opportunity.

Variabelvariabel

yang

memengaruhi permintaan ekspor jahe dan temulawak adalah GDP perkapita riil negara tujuan, populasi negara tujuan, dan jarak ekonomi. Strategi yang dapat dilakukan adalah meningkatkan daya saing komoditas jahe dan temulawak Indonesia dengan melakukan pendekatan Cluster dalam pembanguan industri dan melakukan peningkatan pada faktor kondisi dan strategi perusahaan, struktur dan persaingan.

\section{METODE PENELITIAN}

\section{Jenis dan Sumber Data}

Data penelitian ini menggunakan data sekunder yang bersumber dari beberapa instansi terkait dengan penelitian seperti Kementerian Perindustrian, UNCTAD, Trademap, CEPII, studi kepustakaan melalui pengumpulan data yang bersumber dari buku-buku dan literatur.

\section{Metode Analisis Data}

Metode yang digunakan dalam penelitian ini adalah metode analisis deskriptif dan kuantitatif.Metode deskriptif digunakan untuk menggambarkan perkembangan nilai ekspor kertas Indonesia di Amerika Latin. Metode analisis kuantitatif yang digunakan adalah RCA (Revealed Comparative Advantage), Porter's Diamond Model, EPD (Export Product Dynamic), dan Gravity Model. Dan data yang diperoleh tersebut diolah dengan menggunakan program Microsoft Excel 2007 dan Eviews 6.

\section{Revealed Comparative Advantage (RCA)}

Metode analisis RCA digunakan untuk mengukur daya saing dan menentukan keunggulan komparatif suatu negara di pasar internasional. Pada metode ini dapat dihitung pangsa nilai ekspor komoditi tertentu suatu negara terhadap total ekspor di negara tujuan ekspor yang kemudian dibandingkan dengan pangsa nilai ekspor dunia terhadap total ekspor di negara tujuan ekspor. Rumus umum menghitung nilai RCA dijabarkan pada persamaan (1).

$R C A=\frac{X_{i j} / X_{t j}}{W i j / W t j}$

Nilai RCA suatu komoditi menunjukkan dua kemungkinan, yaitu:

1. Jika nilai RCA > 1, maka suatu negara memiliki keunggulan komparatif diatas rata-rata dunia sehingga komoditi tersebut memiliki daya saing kuat.

2. Jika nilai $\mathrm{RCA}<1$, maka suatu negara memiliki keunggulan komparatif di bawah rata-rata dunia sehingga suatu komoditi memiliki daya saing lemah.

\section{Porter's Diamond Theory}

Porter's Diamond Theory menganalisis faktor-faktor dalam membentuk sistem dan peningkatan keunggulan daya saing. Adapun faktorfaktor utama yang membentuk daya saing duatu komoditu yakni kondisi faktor, kondisi permintaan, industri terkait dan penunjang, serta strategi, struktur, dan persaingan perusahaan. Keempat faktor tersebut didukung oleh peran pemerintah dalam meningkatkan daya saing kertas Indonesia (Porter 1998).

\section{Export Product Dynamic (EPD)}

$\begin{array}{llr}\text { Metode } & \text { analisis EPD digunakan } \\ \text { untuk } & \text { menganalisis }\end{array}$ mengidentifikasi posisi daya saing suatu komoditi untuk mengetahui apakah 
komoditi tersebut kompetitif dan memiliki pertumbuhan yang dinamis. EPD juga mampu membandingkan kinerja ekspor diantara negara-negara seluruh dunia. Posisi daya saing suatu komoditas terdiri dari rising star, lost opportunity, falling star, dan retreat.

Adapun rumus yang digunakan dalam perhitungan EPD dijabarkan pada persamaan (2) dan (3).

Sumbu X : Pertumbuhan pangsa ekspor kertas Indonesia ke Amerika Latin

$$
\text { Sumbu } \mathrm{X}=
$$

$\frac{\sum_{t=1}^{T}\left(\left(\frac{X i j}{W i j}\right) t \times 100 \%-\left(\frac{X i j}{W i j}\right)-1 \times 100 \%\right)}{T-1}$

Sumbu Y : Pertumbuhan pangsa pasar kertas negara Indonesia Amerika Latin

Sumbu $\mathrm{Y}=$ $\frac{\sum_{t=1}^{T}\left(\left(\frac{X t j}{W t j}\right) t \times 100 \%-\left(\frac{X t j}{W t j}\right)-1 \times 100 \%\right)}{T-1}$

Keterangan :

$$
\begin{aligned}
X_{i j}= & \text { Nilai ekspor kertas Indonesia } \\
& \text { ke negara } j \text { (US\$) } \\
X_{t j}= & \text { Nilai ekspor total seluruh } \\
& \text { komoditi Indonesia ke negara } \\
& \mathrm{j} \text { (US\$) } \\
W_{i j}= & \text { Nilai ekspor kertas dunia ke } \\
& \text { negara } j \text { (US\$) } \\
W_{t j}= & \text { Nilai ekspor total seluruh } \\
& \text { komoditi dunia ke negara di } \\
& \text { Amerika Latin (US\$) } \\
= & \text { Negara tujuan } \\
& \text { (Argentina, Brazil, Chile, } \\
& \text { Colombia, Costa Rica, El } \\
& \text { Savador, Guatemala, Peru.) } \\
= & \text { Komoditi rumput laut } \\
\mathrm{i} & \text { Tahun ke-n (n= 2009,..., } \\
& \text { 2013) } \\
= & \text { Banyak tahun analisis }
\end{aligned}
$$

\section{Gravity Model}

Model yang digunakan untuk menganalisis faktor-faktor yang dapat memengaruhi perdagangan antara dua negara berdasarkan hukum gravitasi yaitu Gravity Model. Faktor-faktor tersebut mencakup faktor ekonomi dan non-ekonomi.Variabel-variabel yang akan dianalisis dalam model penelitian ini dijabarkan pada persamaan (2).

$$
\begin{aligned}
& L N N E i t=\beta 0+\beta 1 L N G D P I_{i t}+ \\
& \beta 2 L N G D P J_{j t}+\beta 3 L N H E_{i t}+\beta 4 L N J E_{i j}+ \\
& \beta 5 L N N T_{j t}+\text { eit }
\end{aligned}
$$

Keterangan :

$$
\begin{aligned}
\text { NEit }= & \text { Nilai ekspor kertas } \\
& \text { Indonesia ke negara }(\mathrm{US} \$) \\
\text { GDPIit }= & \text { GDP riil Indonesia pada } \\
& \text { tahun ke-t (US\$) } \\
\text { GDPJjt }= & \text { GDP riil negara tujuan } \\
& \text { ekspor pada tahun ke-t } \\
& \text { US\$) } \\
\text { REERit }= & \text { Nilai tukar riil mata uang } \\
& \text { negara tujuan terhadap } \\
& \text { dollar Amerika (mata uang } \\
& \text { negara tujuan/US\$) } \\
= & \text { Harga produk di pasar dunia } \\
& \text { pada tahun ke-t (US\$) } \\
= & \text { Jarak Ekonomi antar negara } \\
\text { Heit } & \text { Indonesia dan negara tujuan } \\
\text { Jeit }= & \text { error term } \\
\text { Eit } & \text { intercept } \\
\beta 0 \quad & \text { slope }(\mathrm{n}=1,2, \ldots) \\
\beta \mathrm{n} \quad &
\end{aligned}
$$

\section{HASIL DAN PEMBAHASAN}

\section{Gambaran Umum}

Komoditi kertas termasuk komodi manufaktur unggulan Indonesia. Penelitian ini fokus pada ekspor komoditi dari HS 4802 yakni kertas untuk menulis dan mencetak. Nilai ekspor komoditidari Indonesia ke dunia pada tahun 2009-2013 mengalami fluktuasi. Pada tahun 2009 sekitar US\$ 1,708 juta lalu meningkat menjadi US\$ 
2,111 juta pada tahun 2010 dan mengalami penurunan sampai tahun 2013 yang mencapai angka US\$ 1,843 juta dan meningkat lagi menjadi US\$ 1,912 pada tahun 2014. Fluktuasi yang dialami komoditi ini perlu diperhatikan oleh pemerintah Indonesia agar nilai ekspor tersebut tidak turun di pasar dunia (ITC, 2016).

Volume ekspor komoditi kertas dari tahun 2009-2013 mengalami fluktuasi. Pada beberapa negara seperti Argentina, Brazil, dan El Savador mengalami penurunan pada tahun 2013 . Sedangkan di negara lainnya seperti Chili, Colombia, Costa Rica, Guatemala, dan Peru mengalami peningkatan pada tahun tersebut. Peningkatan yang cukup signifikan terjadi di negara Peru yang pada tahun 2012 sekitar 8,533 ton menjadi 12,742 ton pada tahun 2013.Penurunan yang cukup signifikan terjadi di Brazil yang hanya 4,543 ton pada tahun 2013 dibandingkan dengan tahun sebelumnya yang mencapai 10,897 ton (ITC 2016). Penurunan ini salah satu penyebabnya adalah menurunnya jumlah perusahaan terkait sehingga nilai produksi yang dihasilkan juga menurun.

\section{Analisis Daya Saing Kertas Indonesia ke Amerika Latin Periode 2009-2013}

Kondisi yang dijelaskan pada gambaran umum menjadi acuan bagi Indonesia untuk terus meningkatkan ekspor kertas di pasar Amerika Latin. Sehingga perlu diketahui potensi daya saing komoditi tersebut ke negara tujuan ekspor. Perhitungan analisis daya saing ini menggunakan RCA. Hasil analisis RCA komoditi kertas ke Amerika Latin diperlihatkan pada Tabel 2 bahwa ratarata RCA pada delapan negara yang dianalisis memiliki nilai lebih dari satu. Rata-rata ini mengindikasikan bahwa kertas Indonesia memiliki daya saing komparatif yang kuat di negara tujuan ekspor atau memiliki keunggulan komparatif diatas rata-rata dunia. Nilai rata-rata RCA terbesar dimiliki oleh Costa Rica. Selanjutnya diikuti oleh El Savador, Guatemala, Brazil, Peru, Colombia, Chili, dan Argentina.

Tabel 2 Hasil RCA Komoditi Kertas Indonesia ke Amerika Latin

\begin{tabular}{lrrrrrr}
\hline \multirow{2}{*}{ Negara } & \multicolumn{5}{c}{ Tahun } & \multirow{2}{*}{ Rata- Rata } \\
\cline { 2 - 5 } & 2009 & 2010 & 2011 & 2012 & 2013 & \\
\hline Argentina & 0,57 & 1,25 & 0,93 & 1,80 & 1,14 & 1,137 \\
Brazil & 21,25 & 18,17 & 8,99 & 8,18 & 3,42 & 12,002 \\
Chili & 3,96 & 4,33 & 3,82 & 4,51 & 5,94 & 4,512 \\
Colombia & 3,09 & 23,43 & 2,15 & 4,03 & 9,33 & 8,405 \\
Costa Rica & 177,91 & 108,59 & 97,99 & 146,68 & 104,58 & 127,148 \\
El Savador & 60,81 & 77,90 & 73,68 & 92,30 & 134,95 & 87,926 \\
Guatemala & 53,77 & 87,82 & 24,47 & 36,17 & 35,74 & 47,594 \\
Peru & 14,09 & 10,50 & 6,97 & 11,09 & 13,56 & 11,241 \\
\hline
\end{tabular}

Sumber : ITC (diolah) 2016

\section{Analisis Dinamika Ekspor Kertas ke Amerika Latin Periode 2009-2013}

Hasil estimasi EPD kertas Indonesia ke delapan negara Amerika Latin yaitu berada pada posisi rising star di tiga negara yakni Argentina, Guatemala, dan Peru, berada pada posisi retreat di dua negara yakni Brazil dan Chili, berada pada posisi falling star di dua negara yakni Colombia dan El Savador, dan berada pada posisi lost opportunity di satu negara yakni Costa Rica. Posisi rising star ini mengindikasikan bahwa negara tersebut 
memperoleh tambahan pangsa pasar dan pertumbuhan permintaan ekspor kertas Indonesia. Lost opportunity mengindikasikan bahwa adanya peningkatan permintaan terhadap ekspor kertas Indonesia di negara tersebut namun pangsa pasar ekspor kertas Indonesia di negara tersebut menurun artinya Indonesia kehilangan kesempatan mengoptimalkan pasar yang dinamis untuk mendapatkan keuntungan. Falling star mengindikasikan bahwa pangsa pasar ekspor kertas Indonesia di negara tersebut mengalami peningkatan namun permintaan terhadap kertas menurun. Retreat posisi ini mengindikasikan bahwa pangsa pasar ekspor dan permintaan ekspor kertas di negara tersebut mengalami penurunan. Hasil estimasi EPD ditunjukkan pada Tabel 3.

Tabel 3 Hasil EPD Kertas Indonesia ke Amerika Latin

\begin{tabular}{lrrl}
\hline Negara & Sumbu X & Sumbu Y & Posisi Pasar \\
\hline Argentina & 0.463 & 0.031 & Rising star \\
Brazil & -0.331 & -0.015 & Retreat \\
Chili & -0.027 & -0.134 & Retreat \\
Colombia & 2.148 & -0.021 & Falling Star \\
Costa Rica & -0.108 & 0.018 & Lost Opportunity \\
El Savador & 0.181 & -0.029 & Falling Star \\
Guatemala & 0.312 & 0.119 & Rising star \\
Peru & 0.160 & 0.168 & Rising star \\
\hline
\end{tabular}

\section{Analisis Faktor-Faktor yang Memengaruhi Ekspor Kertas Indonesia ke Amerika Latin}

Penelitian ini menganalisis faktorfaktor yang memengaruhi nilai ekspor kertas Indonesia ( $\left.\mathrm{NE}_{\mathrm{it}}\right)$ ke Amerika Latin digunakan gravity model.Variabel independen yang digunakan dalam penelitian ini adalah GDP riil Indonesia (GDPI $\left.{ }_{i t}\right)$, GDP riil negara tujuan $\left(\mathrm{GDPJ}_{\mathrm{jt}}\right)$, harga kertas Indonesia ke negara tujuan ekspor $\left(\mathrm{He}_{\mathrm{j} t}\right)$, jarak ekonomi Indonesia dengan negara tujuan ekspor $\left(\mathrm{Je}_{\mathrm{ij}}\right)$, dan nilai tukar riil efektif negara tujuan ekspor $\left(\mathrm{NT}_{\mathrm{jt}}\right)$.

Pemilihan model dilakukan dengan melakukan uji Chow dan uji Hausman. Nilai probabilitas yang dilakukan pada uji Hausman (Lampiran 6) sebesar 0,0002 (lebih kecil dari taraf nyata $5 \%$ ) sedangkan nilai probabilitas pada hasil uji Chow (Lampiran 5) sebesar 0,0000 (lebih kecil dari taraf nyata $5 \%$ ) maka tolak $\mathrm{H}_{0}$. Artinya, penelitian ini dalam pengolahan datanya menggunakan metode efek tetap (fixed effect). Hasil estimasi dilihat pada Tabel 4.

Hasil estimasi menunjukkan bahwa variabel yang memengaruhi nilai ekspor kertas Indonesia adalah GDP riil Indonesia, GDP riil negara tujuan, harga ekspor, dan jarak ekonomi sedangkan nilai tukar tidak berpengaruh signifikan terhadap nilai ekspor kertas Indonesia ke Amerika Latin. Setelah model terpilih kemudian dilakukan uji kriteria ekonometrika. Model yang digunakan dalam ekspor kertas adalah sebagai berikut :

LNNEit $=16,2014-4,537083$ LNGDPIit + 4,416753 LNGDPJjt 3,539672 LNHEit - 1,797085 LNJEij

Uji heteroskedastisitas dapat dilakukan dengan membandingkan nilai Sum Square Resid pada weighted statistics dan unweighted statistics. Pada 
estimasi model ini menunjukkan bahwa nilai Sum Square Resid pada weighted statistics sebesar 5,460143 lebih kecil dari Sum Square Resid pada unweighted statistics yang memiliki nilai 7,791530.
Hal ini mengindikasikan bahwa terdapat permasalahan heteroskedastisitas pada model tersebut, namun dapat diabaikan karena estimasi model menggunakan pembobotan cross-section.

Tabel 4 Hasil Estimasi Gravity Model Ekspor Kertas Indonesia ke Amerika Latin dengan metode fixed effect

\begin{tabular}{lcr}
\hline Variabel & Koefisien & Prob \\
\hline LNGDPI & $-4,5371$ & $0,0423^{*}$ \\
LNGDPJ & 4,41675 & $0,0754^{*}$ \\
LNHE & $-3,5397$ & $0,0003^{*}$ \\
LNJE & $-1,7971$ & $0,0278^{*}$ \\
LNNT & 1,97798 & 0,1365 \\
C & 16,2014 & 0,3499 \\
\hline \multicolumn{2}{c}{ Weighted Statistics } \\
\hline Prob(F-statistic) & 0,90884 Sum squared resid & 5,46014 \\
\hline \multicolumn{4}{c}{ R-squared } & 0,00000 & Durbin-Watson stat \\
Sum squared resid & Unweighted Statistics & 1,83916 \\
\hline Keterangan & 0,84047 & Mean dependent var \\
\hline
\end{tabular}

Keterangan : *) Signifikan pada taraf nyata 5\%

**) Signifikan padataraf nyata $10 \%$

Lalu pada Standardized Residual Graph menunjukkan bahwa grafik berfluktuatif.

Uji autokorelasi dapat dilakukan dengan melihat nilai Durbin-Watson. Model ini memiliki nilai DW sebesar 1,839157. Dengan jumlah variabel independen sebanyak lima, taraf nyata sebesar 5 persen, dan observasi sebanyak 40 maka diperoleh nilai Durbin-watson tabel dengan du sebesar 1,28484. Maka nilai DW berada diantara $\mathrm{du}<\mathrm{DW}<2$, artinya terima $\mathrm{H}_{0}$ dan tidak ada autokorelasi.

Uji multikolinearitas dilakukan dengan cara melihat matriks korelasi antar variabel independen. Jika nilai variabel pada matriks melebihi nilai $R$ squared pada model yaitu 0,908843 maka terdapat multikolinearitas. Pada model ini terlihat uji multikolinearitas bahwa tidak ada nilai variabel yang melebih nilai $R$-squared pada model. Hal ini menunjukkan bahwa tidak terjadi permasalahan multikolinearitas pada model ini.

Uji normalitas pada data panel diperlukan untuk melihat normal atau tidaknya error term suatu model. Uji normalitas dapat dilakukan dengan melihat nilai Jarque-Bera dan nilai probabilitas pada histogram normality test. Pada hasil uji normalitas menunjukkan bahwa model ini memiliki nilai Jarque-Bera sebesar 0,976783 dan nilai probabilitas sebesar 0,613613 dimana keduanya memiliki nilai lebih besar dari taraf nyata $5 \%$ yang mengindikasikan bahwa error term pada moda model telah menyebar normal.

\section{Interpretasi Model}

\section{GDP riil Negara Indonesia}

GDP riil Indonesia memiliki nilai probabilitas yaitu sebesar 0,0423 . Nilai ini signifikan pada taraf nyata $5 \%$ yang 
menunjukkan bahwa GDP riil Indonesia berpengaruh signifikan terhadap nilai ekspor kertas Indonesia. Hasil estimasi sesuai dengan hipotesis yang mengasumsikan bahwa GDP riil memiliki hubungan negatif dengan nilai ekspor kertas Indonesia. Hal ini menunjukkan bahwa setiap kenaikan GDP riil Indonesia sebesar 1\% maka nilai ekspor kertas ke delapan negara di Amerika Latin mengalami penurunan sebesar 4,537083\% (cateris paribus). Kenaikan GDP riil Indonesia dapat meningkatkan daya beli masyarakat domestik sehingga konsumsi kertas di dalam negeri meningkat yang akhirnya menyebabkan ekspor kertas Indonesia ke Amerika Latin menurun. Hasil estimasi ini didukung oleh penelitian Yunia (2015).

\section{GDP riil Negara Tujuan Ekspor}

GDP riil negara tujuan ekspor memiliki nilai probabilitas yaitu sebesar 0,0754. Nilai ini signfikan pada taraf nyata $10 \%$ yang menunjukkan bahwa GDP riil negara tujuan ekspor berpengaruh signifikan terhadap nilai ekspor kertas Indonesia. Hasil estimasi sesuai dengan hipotesis bahwa GDP riil negara tujuan memiliki hubungan positif terhadap nilai ekspor kertas Indonesia. Hal ini mengindikasikan bahwa setiap kenaikan GDP negara tujuan sebesar $1 \%$ maka nilai ekspor kertas Indonesia ke Amerika Latin mengalami peningkatan sebesar 4,41675\% (cateris paribus). Kenaikan GDP delapan negara tujuan ekspor mengindikasikan bahwa daya beli penduduk negara tujuan yang tinggi terhadap kertas Indonesia sehingga permintaan ekspor akan meningkat.

\section{Harga Ekspor}

Harga ekspor kertas Indonesia memiliki nilai probabilitas sebesar 0,0003 . Nilai ini signifikan pada taraf nyata 5\% yang menunjukkan bahwa harga ekspor kertas Indonesia berpengaruh signifikan terhadap nilai ekspor kertas Indonesia. Hasil estimasi sesuai dengan hipotesis bahwa harga ekspor memiliki hubungan negatif terhadap nilai ekspor kertas Indonesia. Hal ini mengindikasikan bahwa setiap kenaikan harga ekspor kertas Indonesia sebesar 1\% maka nilai ekspor kertas Indonesia ke Amerika Latin mengalami penurunan sebesar 3,539672\% (cateris paribus). Kenaikan harga ekspor kertas Indonesia menyebabkan nilai ekspor kertas Indonesia ke Amerika Latin mengalami penurunan.

\section{Jarak Ekonomi}

Jarak ekonomi antara Indonesia dengan delapan negara tujuan ekspor di Amerika Latin memiliki nilai probabilitas sebesar 0,0278. Nilai ini signifikan pada taraf nyata $5 \%$ yang menunjukkan bahwa jarak ekonomi berpengaruh signifikan terhadap nilai ekspor kertas Indonesia. Hasil estimasi sesuai dengan hipotesis bahwa jarak ekonomi memiliki hubungan negatif terhadap nilai ekspor kertas Indonesia. Hal ini mengindikasikan bahwa setiap bertambahnya jarak ekonomi antara Indonesia dengan negara tujuan sebesar $1 \%$ maka nilai ekspor kertas Indonesia akan mengalami penurunan sebesar 1,797085\%. Peningkatan jarak ekonomi mengindikasikan biaya transportasi untuk pengangkutan semakin meningkat karena semakin jauh jarak yang harus ditempuh sehingga akan berdampak pada penurunan ekspor kertas Indonesia.

\section{Nilai Tukar}

Nilai tukar (REER) negara tujuan ekspor memiliki nilai probabilitas sebesar 0,1365. Nilai ini tidak siginifikan pada taraf nyata $5 \%$ yang menunjukkan bahwa nilai tukar tidak 
berpengaruh signifikan terhadap nilai ekspor kertas Indonesia. Hasil estimasi tidak sesuai dengan hipotesis yang mengasumsikan bahwa nilai tukar memiliki hubungan negatif dengan nilai ekspor kertas Indonesia. Hasil estimasi menunjukkan bahwa nilai tukar negara tujuan memiliki hubungan positif dengan nilai ekspor kertas Indonesia. Hal ini dikarenakan REER merupakan nilai tukar yang dipengaruhi oleh pembobotan perdagangan dengan negara-negara mitra dagang. Pembobotan ini menyebabkan hubungan antara kedua variabel menjadi positif karena Indonesia juga banyak melakukan ekspor barang komoditas primer seperti minyak bumi dan gas alam (Utami, 2008).

\section{Analisis Porter's Diamond}

\section{Kondisi Faktor}

1. Hutan tanaman Industri (HTI) merupakan hutan produksi berbagai produk kayu dan turunannya. HTI juga merupakan sumber bahan baku kertas. Pada tahun 2011 luas HTI sebesar 10,04 juta Ha mengalami penurunan menjadi 9,83 juta $\mathrm{Ha}$ pada tahun 2012. enurunan luas HTI ini sebesar 2,11\% (APKI 2013).(-)

2. Iklim di Indonesia membuat umur pohon yang menjadi sumber bahan baku kertas seperti akasia dan eucalyptus dapat dipanen saat berumur 5 sampai dengan 7 tahun. Umur panen ini lebih singkat dibandingkan dengan Negara lainnya. Hal ini membuat biaya produksi kertas di Indonesia lebih rendah dibandingkan negara pesaingnya (Handayani 2008). (+)

3. Produktivitas tenaga kerja sub sektor kertas mengalami fluktuatif namun cenderung meningkat. Pertumbuhan produktivitas tenaga kerja pada periode tahun 2009 sampai 2013 sebesar 23\% . (+)

4. Pengelolaan lahan gambut yang akan dijadikan HTI sebagai sumber bahan baku kertas sudah menggunakan teknologi ekohidro. Teknologi ini memastikan pengaturan muka air dikawasan HTI yang dikelola dapat dilakukan secara lebih akurat. (+)

5. Berdasarkan USDOC Internasional Trade Administration, mesin dan suku cadang yang digunakan di pabrik pengolahan pulp dan kertas hampir $100 \%$ masih diimpor dari luar negeri dan tidak ada produksi mesin lokal. Hal ini mengakibatkan sebagian besar produsen harus melakukan perawatan terhadap mesin pengolahan yang dimiliki (APKI 2013). (-)

6. Jumlah industri dan total nilai produksi kertas di Indonesia mengalami penurunan (Kemenperin 2016). (-)

\section{Kondisi Permintaan}

1. GDP Amerika Latin meningkat setiap tahunnya. Salah satunya negara Peru yang mengalami peningkatan GDP sebesar $23 \%$ dari periode tahun 2009-2013 (UNCTAD 2016). (+)

2. Nilai RCA $>1$ yang menunjukkan bahwa komoditi kertas Indonesia memiliki daya saing komparatif yang kuat. $(+)$

3. Jumlah penduduk Amerika Latin yang meningkat setiap tahun sehingga berpotensi menjadi negara tujuan ekspor (UNCTAD 2016). (+)

\section{Industri Terkait dan Penunjang}

1. Asosiasi pulp dan kertas Indonesia (APKI) melakukan upaya peningkatan kinerja industri pulp dan kertas Indonesia dengan 
mengajukan revisi Permendag 64/2012 jo 81/2013 tentang ketentuan ekspor produk industri kehutanan kepada pemerintah. Upaya ini dilakukan agar hanya produk hulu kertas yang terkait langsung dengan kayu yang harus memiliki mandatory sertivikasi sistem verifikasi dan legalitas kayu (SVLK) dan produk turunannya tidak perlu dikenakan kewajiban memenuhi SVLK. Karena apabila produk hulunya sudah disertifikasi hal ini menunjukkan bahwa legalitas produk hilirnya sudah terjamin (APKI 2013). (+)

2. Perusahaan kesulitan mengelola hutan tanaman industri (HTI) karena banyaknya tekanan yang dihadapi. Tekanan tersebut seperti kampanye greenpeace yang dilakukan oleh lembaga NonGovernmental Organizatinon (NGO) yang menuduh bahwa HTI tidak ramah terhadap lingkungan dan banyak lahan yang digarap oleh masyarakat di kawasan HTI tanpa seperizinan dari perusahaan yang mengelola (APKI 2013). (-)

3. Perusahaan Sinar Mas Forestry menginvestasikan dana hingga US\$ 324 juta atau sekitar 3.12 triliun rupiah untuk merealisasikan periode tanam (HTI) seluas 217,823 hektar di lahan gambut Ogan Komering Ilir, Sumatera Selatan (APKI 2013). $(+)$

\section{Strategi, Struktur, dan Persaingan Perusahaan}

1. Industri kertas Indonesia berada pada peringkat keenam dunia dan ketiga di Asia (Kemenperin 2016). $(+)$

2. Pengalihan penggunaan kertas ke media elektronik atau portal berita. $(-)$
3. Industri kertas Riau Andalan Pulpand Paper (RAPP) sudah memiliki sertifikasi SVLK industri, standar produk kayu spert chain of custody, dan controlled wood dari Forest Stewardshi Council (FSC), ecolabel, dan ISO Environmental System. Kelengkapan sertifikasi ini membuat perusahaan dapat bersaing di pasar ekspor (APKI 2013). (+)

4. Asia Pulp and Paper (APP) adalah perusahaan pertama di sektor industri kertas dan pulp se-Asia Pasifif yang mendapatkan penilaian level advanced dari lembaga Independen Societe Generale de Surveillance karena telah menerapkan standar tanggung jawab ISO 26000. ISO 26000 merupakan seperangakat pedoman praktik terbaik untuk tata kelola organisasi, praktik hubungan ketenagakerjaan, lingkungan hidup, praktik operasional yang adil, isu konsumen, serta ketertiban dan pengembangan masyarakat setempat (APKI 2013). (+)

\section{Peran Pemerintah}

1. Penerapan sistem standarisasi dan sertifikasi baik terhadap produk, personel, maupun sarana dan prasarana pendukungnya. Produkproduk kertas Indonesia kebanyakan sudah Standar Nasional Indonesia (SNI) (APKI 2013). (+)

2. PP RI No 8 Tahun 1999 tentang pengelolaan bahan berbahaya dan beracun (B3) membuat para industri dan pengusaha kertas merasa diberatkan. Hal ini dikarenakan setiap limbah dianggap sebagai limbah B3 yang berbahaya dan beracun tanpa memberikan batasan konsentrasi atau volume jumlah dalam pengkategoriannya. Padahal ada beberapa jenis limbah yang tidak berbahaya dan bisa dijadikan 
sebagai bahan baku lagi (APKI 2013). (-)

3. Permendag No 64/2012 yang mengharuskan seluruh ekspor produk kertas, baik yang berbahan kayu maupun nonkayu, harus dilengkapi dengan dokumen Vlegal sebagai output dari sistem verifikasi legalitas kayu (SVLK) (APKI 2012). (-)

4. Kebijakan kenaikan harga BBM dan tarif dasar listrik (TDL) pada awal tahun 2013 memengaruhi kinerja industri kertas menurun sebesar $0.92 \%$ (APKI 2013). (-)

5. Pemerintah berupaya menerapkan Green Industry pada industri pulp dan kertas. Sebagian industri pulp dan kertas yang menerapkan green industry telah mampu menghemat penggunaan energi fosil dengan memanfaatkan lignin dari limbah produksi. Lignin kayu ini diproses menjadi lignin hitam pekat yang mampu untuk menggantikan penggunaan bahan bakar fosil dalam proses produksi pulp dan kertas sampai 87\% (APKI 2013). (+)

\section{Kesempatan}

1. Kondisi pasar ekspor kertas Indonesia di Argentina, Guatemala, dan Peru yaitu rising star. (+)

2. Kondisi pasar ekspor kertas Indonesia di Brazil dan Chili yaitu retreat. (-)

3. Kondisi pasar ekspor kertas Indonesia di Costa Rica yaitu lost opportunity. $(+)$

4. Kondisi pasar ekspor kertas Indonesia di Colombia dan El Savador yaitu falling star. (-)

5. Komoditi kertas termasuk sepuluh besar komoditi manufaktur unggulan Indonesia di pasar Amerika Latin (Kemendag 2016). $(+)$

6. GDP riil negara tujuan dapat menjadi acuan untuk mengekspor kertas Indonesia.

Diagram analisis Porter's Diamond ditunjukkan pada Gambar 3. 


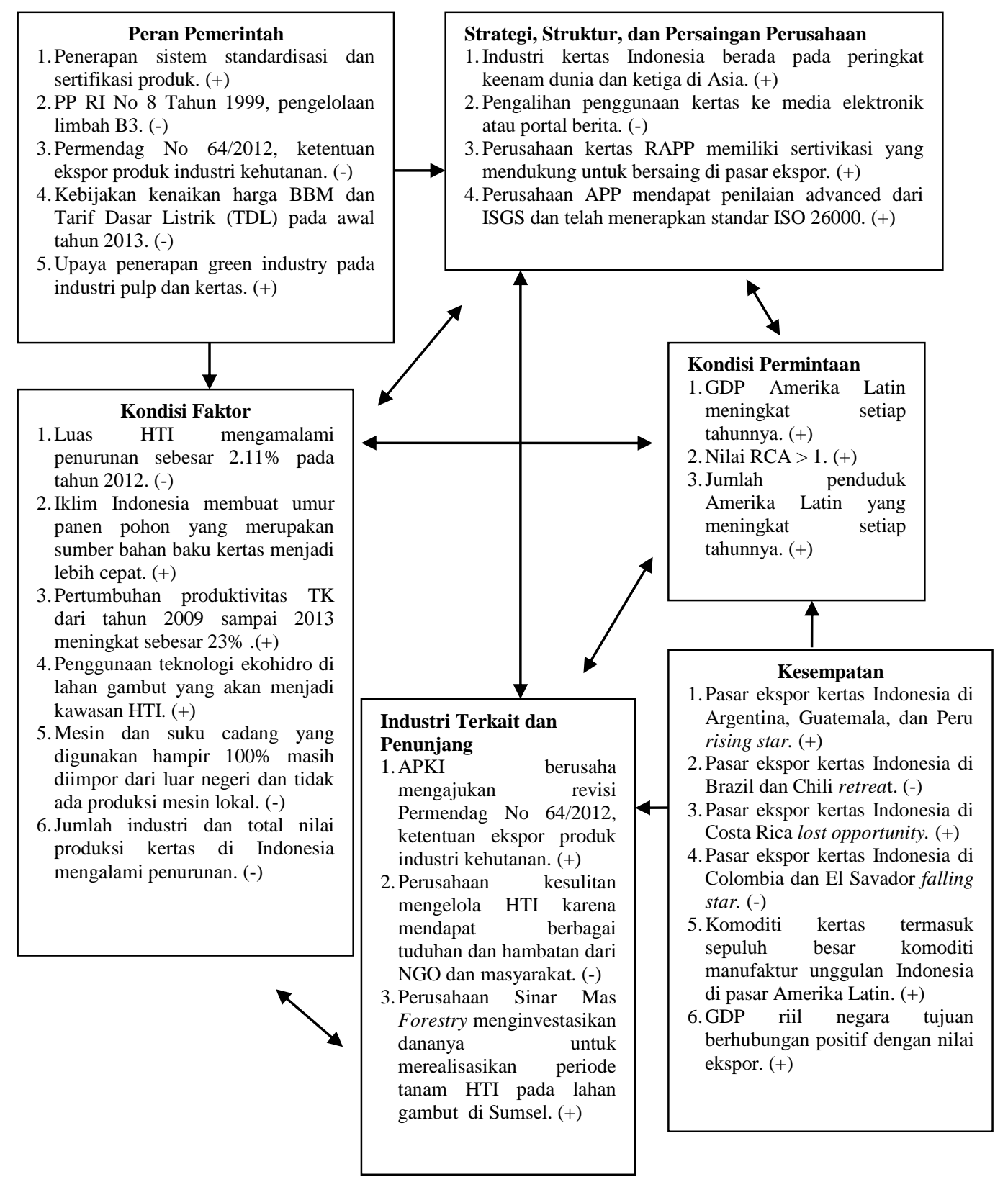

Gambar 3 Diagram analisis Porter's Diamond 


\section{KESIMPULAN DAN SARAN}

\section{Kesimpulan}

Simpulan dari penelitian ini adalah:

1. Pada hasil analisis RCA menunjukkan bahwa kertas Indonesia memiliki daya saing komparatif yang kuat di delapan negara Amerika Latin. Hal ini ditunjukkan pada nilai rata-rata RCA lebih besar dari 1.

2. Hasil analisis EPD komoditi kertas Indonesia menunjukkan bahwa ada tiga negara yang menempati posisi rising star yakni Argentina, Guatemala, dan Peru. Satu negara berada pada posisi lost opportunity yakni Costa Rica. Lalu dua negara pada kondisi falling star yakni Colombia dan El Savador. Kemudian dua negara pada kondisi retreat yakni Brazil dan Chili.

3. Hasil estimasi gravity model menunjukkan bahwa GDP riil Indonesia, harga ekspor, dan jarak ekonomi memiliki hubungan negatif dengan nilai ekspor dan berpengaruh signifikan. Lalu GDP riil negara tujuan memiliki hubungan positif dengan nilai ekspor dan berpangaruh signifikan. Sedangkan nilai tukar riil efektif memiliki hubungan positif dengan nilai ekspor dan tidak signifikan.

4. Pada hasil analisis Porter's Diamond menunjukkan bahwa komponen unggulan kertas Indonesia adalah kondisi faktor, kondisi permintaan, industri terkait dan penunjang, kesempatan serta strategi, struktur, dan persaingan perusahaan. Sedangkan peran pemerintah menjadi kelemahan pada industri kertas Indonesia.

5. Kinerja ekspor kertas Indonesia cukup potensial ke beberapa negara Amerika Latin. Hal ini dapat dilihat dari seluruh hasil analisis yang menunjukkan bahwa kertas memiliki daya saing yang kuat namun di beberapa negara kertas berada pada posisi pasar yang lemah.

\section{Saran}

1. Pemerintah perlu melakukan upaya meningkatkan ekspor kertas Indonesia dengan memperhatika negara- negara yang memiliki GDP tinggi.

2. Pemerintah perlu memberikan perhatian pada negara Costa Rica karena ekspor kertas Indonesia ke negara tersebut memiliki pasar yang dinamis bagi ekspor kertas Indonesia. Pemerintah perlu mengoptimalkan pasar yang dinamis untuk mendapatkan keuntungan.

3. Pemerintah perlu melakukan diversifikasi komoditi pada negara yang berada pada kondisi falling star dan retreat.

\section{DAFTAR PUSTAKA}

[APKI] Asosiasi Pulp dan Kertas Indonesia 2013 [diunduh 2016 Maret 1]. Tersedia pada: http://www.apki.net

[BPS] Badan Pusat Statistik [Internet]. [diunduh 2016 Februari 26]. Tersedia pada: http://bps.go.id

[CEPII] Centre d'Etudes Prospectives et d'Informations Internasionales. Geodesic Distance [Internet]. [diunduh 2016 Februari 21]. Tersedia pada: http://www.cepii.fr/distance/dist_c epii.zip

Dornbusch R, Fischer S, dan Start R. 2008. Makroekonomi. Terjemahan dari: Macroeconomics. Mirazudin RI, penerjemah. Wibisono $\mathrm{Y}$, editor. Ed ke-10 Penerbit PT Media Global Edukasi. 
Firsya AF. 2014. Analisis Daya Saing dan Faktor-Faktor yang Memengaruhi Aliran Ekspor Komoditas Kakao Olahan Indonesia [Skripsi]. IPB. Bogor

Handayani N. 2008. Analisis FaktorFaktor yang Mempengaruhi Aliran Perdagangan dan Strategi Pengembangan Ekspor Kertas Indonesia [Skripsi]. IPB. Bogor.

[ITC] International Trade Centre. [diunduh 2016 Februari 21]. Tersedia pada: http://www.trademap.org/Bilateral _TS.aspx

Karagoz K, Saray MO. 2009. Trade Potential of Turkey with AsiaPacific Countries: Evidence from Panel Gravity Model. Internasional Economics Studies. 36 (1): 20-26. (TUR)

Kementerian Perindustrian Republik Indonesia. 2015. http://www.kemenperin.go.id [ 24 Februari 2016

Mankiw NG. 2007. Makroekonomi, Terjemahan dari: Macroeconomics $6^{\text {th }}$. Fitria L, Imam N, penerjemah. Penerbit Erlangga.
Porter M. 1990. The Competitive Advantage of Nations. Harvard Business Review. [USA]

Salvatore D. 1997. Ekonomi Internasional. Haris $\mathrm{M}$, penerjemah. Jakarta (ID): Penerbit Erlangga. Terjemahan dari: International Economic.

[UNCTADSTAT] United Nations Conference on Trade and Development. [diunduh Februari 2016]. Tersedia pada: http://unctadstat.unctad.org

Utami LC 2008. Variabel-Variabel Determinan Ekspor ASEAN: Studi Kasus Indonesia, Thailand, Singapura, Filipina Tahun 19902006. Skripsi. Depok (ID) : Universitas Indonesia.

Yunia, SN. 2015. Analisis Daya Saing dan Faktor-Faktor yang Memengaruhi Ekspor Alas Kaki Indonesia ke Amerika Latin Skripsi. Bogor (ID) : Institut Pertanian Bogor.

Yuniawati, IP. 2013. Analisis Daya Saing serta Faktor-Faktor yang Memengaruhi Permintaan Jahe dan Temulawak Indonesia di Lima Negara Tujuan Ekspor. Skripsi. IPB. Bogor. 